\title{
ИНТЕРПРЕТАЦИІЕ БОСАНСКОХЕРЦЕГОВАЧКОГ ЈЕЗИЧКОГ ИЗРАЗА И ЈЕЗИЧКЕ ПОЛИТИКЕ КОЈА ГА ЈЕ ПРАТИЛА
}

Апстракт: Језичка политика у СР Босни и Хериеговини, нарочито период од 1967. године, интересантна је из два разлога: први пут се ова југословенска република - нени политичари и лингвисти - укьучује у расправе о језику, и друго, говори се о специфичностима босанскохерчеговачког језичког израза. Ту језичку политику пратимо на основу конферениија и савјетована одржаних у СР Босни и Херцеговини, званичних докумената, те ставова лингвиста и политичара тог доба. Без обзира на различита тумачена овог периода, историја је ипак показала да је ова политика, након што се неколико година заиста спроводила, била почетак даљег комадать језика. Показаћемо то служећи се Радовановићевом подјелом на фазе стандардизачије језика.

Кључне ријечи: Босна и Херцеговина, босанскохерчеговачки језички израз, језичка политика, јавна политика.

\section{1. Уводне напомене}

Често је у Аруштвима какво је босанскохерцеговачко незахванно писати о језику управо због чињенице да су његов статус и развој осјетьива питања у која је мало ко успио проникнути без уплитања вјерских и национацних односа у истраживање. Овај рад не претендује да изнесе коначан став о питању језика у предратним годинама, он је настао у покушају да се анализира двадесетогоАишња језичка политика у овој југословенској републици а да се не залази у оцјену исправности те помитике.

Самостална језичка помитика Босне и Херцеговине трајала је од 1967. (1970) до распада СФРЈ, а бима је одговор на разлаз међу српским и хрватским 


\section{АЛЕКСАНДРА Р. САВИЋ}

Аингвистима око назива и положаја заједничког језика. Подразумијеваха је Авочлани назив језика, употребу оба писма и поштовање принципа језичке толеранције и индивидуалне језичке слободе. Радило се о добро осмишьеном пројекту и вриједи истражити који су кораци бими нужни за озваничење једне јавне политике, како се она развијала и да $и$ је пратила унапријед означене циљеве, зашто је престаца да важи и, напосьетку, Аа ми је убрзала или успорима касније распарчавање језика. Аа би бима објашњена, именована и спроведена у Ајело, њени су творци морами предочити јавности и науци и Аингвистичке и ваниингвистичке, што ће рећи социолингвистичке разцоге за њено постојање jep

unutrašnji lingvistički kriteriji ni u sinkronijskom (tipološka klasifikacija) ni u dijakronijskom (genetska klasifikacija) presjeku nisu uvijek dovoljni da se pojedini idiomi međusobno diferenciraju u jasno razlučene (i razlučive) jedinice u skupu jezika svijeta. U razdoblju buđenja nacionalne svijesti unutarlingvističkim kriterijumima pridodan je i jedan vanjski, etnički ${ }^{2}$ (Škiljan 1988: 22).

Аакме, ови језички и ванјезички постулати, заједно с политичком вољом и обимним истраживањима, требало је да Босну и Херцеговину изузму из расправа о српскохрватском језику и да понуде трајно језичко рјешење за њене грађане. Овај рад управо прати настанак, положај, развој и документе босан-

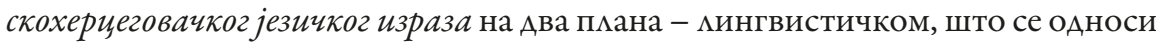
на сва теоријска полазишта која су апологети самосталне језичке политике користики како би одбраними овај концепт, и социолингвистичком, који се тиче друштвеног оправдања за увођење посебног израза.

\section{2. Почетак самосталне помитике}

Случај који је одредио пут самосталне језичке политике Босне и Херцеговине и који је био „преломни догађај послије Новосадског договора значио је Пети конгрес југословенских слависта“ (Tanasić 2012: 67). Послије полемика, конгреса у Сарајеву и озваниченог удаљавања од заједничког језика, „непосреАан повод за укьучивање државно-партијских тијела у вођење језичке политике у БиХ“ ('Tanasić 2012: 75) бики су Аекларација о називу и положају хрватског књижевног језика (1967) и Предлог за размишьағе (1967), који су у Босни и

${ }^{2}$ У овом случају мултинационални. Аефиниција функционише у оба смјера - националном и наднационамном. 
Херцеговини дочекани као „штетни и опасни по заједништво и националне односе“ (Šipka 2005: 428). Притом, буктала је ватра међу српским и хрватским мингвистима, па су те полемике „обавезивале босанскохерцеговачке политичке снаге Аа се језичком проблематиком стално баве“" (Tanasić 2012: 78).

Језичка политика СР Босне и Херцеговине заснивала се на неколико значајних докумената: изјавама ИК ЦК СКБИХ из 1967. и 1968. гоАине, Закьучцима Симпозијума о језичкој томеранцији у настави - у школама СР БИХ (1970), Аокументу Аруштвено-политичких организација Књижевни језик и књижевнојезичка политика у Босни и Херцеговини (1971), Закьучцима Просвјетно-културног вијећа Скупштине СР БИХ о књижевнојезичкој политици у васпитно-образовној Ајелатности (такође 1971), Закьучцима Мостарског савјетовања о провођењу књижевнојезичке политике у Босни и Херцеговини (1973) и Ставовима Извршног комитета Предсједништва ЦК БИХ о провођењу књижевнојезичке политике (1974) (Šipka 1987: 32).

Ти акти изражавали су ставове вмасти и мингвиста, што се може примијетити и из самих назива списа, будући да је малтене једнак број оних који имају предзнак неког политичког тијела и оних које су потписали стручњаци. Сви они имали су циљ да у овој социјалистичкој републици инаугуришу а) самосталну језичку политику б) докажу њену политичку и језичку оправданост.

Што се тиче првог услова, он је био испуњен самом чињеницом да је постојала сагласност свих кьучних друштвенополитичких актера за провођење новог концепта. Садржина те политике ${ }^{3}$ била је изнесена четирима принципима чије су основне поруке толеранција и слобода избора а „у ова четири кратка и јасна става сажета је суштина књижевнојезичке политике у БИХ - њена Аруштвена и мингвистичка заснованост, њени документи и поруке, њен хумани смисао“, писао је тада њен главни протагонист Микан Шипка $(1975: 23)^{4}$. Провођење ових начела - што је Аруги горе назначени услов -

${ }^{3}$ „1. Прихватање хрватскосрпског односно српскохрватског књижевног језика као једног језика са свим разноликостима и варијантним разликама; 2 . Отвореност према позитивним културним и језичким утицајима из свих република и свих културних средишта нашег језичког подручја; 3. Његовање аутохтоних књижевнојезичких и културних вриједности, које су заједничко благо свих народа БиХ и чине мост међу њиховим културама, тј. инсистирање на ономе што нас повезује и зближава и 4. Пуна слобода индивидуалног избора језичких изражајних средстава, без обзира на њихову варијантску маркираност у другим срединама“( Šipka 1975: 23).

${ }^{4}$ Бимо би интересантно истражити улогу Милана Шипке у креирању босанскохерцеговачке језичке политике. Наиме, ради се о човјеку који је био у самом епицентру дешавања, поједине закьучке и кораке је и сам осмислио, а данас се његов рад слабије проучава. Међутим, зачуђује 
ишло је теже управо због чињенице да је цјелокупан план рјешавања проблема стандардног језика зависио од одбране термина босанскохерцеговачки језички израз и оА истраживања која би омогућима доказе за постојање самосталног концепта који се теоријски и у пракси размикује од израза других средина и који би након исцрпних испитивања могао бити и нормиран.

С обзиром на то Аа се цјелокупна језичка политика заснивала управо на верзији самосталног, „аутохтоног“, касније „аутентичног“ израза народа и народности Босне и Херцеговине, мингвисти су имали задатак да за своје ставове нађу упориште у науци и у Аруштву, те су почетне године те језичке политике биме посвећене теоријским разматрањима угледних мингвиста из Босне и Херцеговине али и цијеле државе о варијантама српскохрватског језика. Још у почетку су неки мингвисти примијетили да прокламовани ставови нису поткрепьени научним аргументима и да је изостао „стручан осврт“ (Baotić према Tanasić 2012: 77). Недуго послије тога, Аруштвени односно социолингвистички аргументи иду руку под руку с мингвистичким, политичке ставове прате стручна засједања и научне конференције и они ће наредних двадесет година, колико је трајала босанскохерцеговачка језичка политика, чинити неодвојиви дио те политике. Курс саме политике мијењан је неколико пута а та преобликовања најбове илуструје појам босанскохерцеговачки језички израз - у првим документима одбачено је постојање бимо какве босанскохерцеговачке варијанте ${ }^{5}$, затим је, након оснивања Института за језик, озваничено постојање управо тог израза, да би након неколико година он био замијењен неутрацнијим - стандарднојезички израз у Босни и Хериеговини.

\section{3. Босанскохерчеговачки језички израз}

Многи Аингвисти прикьучими су се расправи о босанскохерцеговачкој језичкој политици и даци свој допринос њеном расвјетьавању, а неки од њих остали су изван тих расправа, што због неслагања с доминантним тезама што

разноликост ставова о његовом именовању на чело Института за језик у Сарајеву и његовом залагању за босанскохериеговачки језички израз. Размог мог интересовања за његов рад била је једна сасвим незнатна Аогичка неподударност - код једног мингвисте сам прочитала Аа је Шипка крив што је у Скупштини СФРЈ направьено осам секција за језик, од којих су Авије омогућиме успоставњање нових језика на Балкану, а код Шипке и у званичном допису, с Аруге стране, пише - управо супротно. Шта је оА тога истина, да Аи је овај Аингвиста покушао спасити језик од цијепања или је и сам проводио експеримент над језичким питањима, неко ће већ открити.

$152{ }^{5}$ Симпозијум о језичкој толеранцији (Tanasić 2012: 80). 
због немијешања у унутрашња питања ове југословенске Аржаве. ПореА тога, понекад се истиче Аа је „за спровођење ове политике бимо потребно довести нове кадрове безрезервно опредијељене за такав концепт, макар и недовољно афирмисане језичке посменике“ (Baotić 2012: 89). У митератури се налази много разцичитих тумачења природе и статуса босанскохерщеговачког језичког израза а његово „inauguriranje (...) moralo je samo po sebi izazvati reakcije. Novo stanje, naime, nije se uklapalo ni u koncept tzv. separatista, pogotovo ne u koncept integralista“" (Baotić 2012: 357). Бимо је важно новој језичкој политици обезбиједити вањане теоријске темење, па су се неколико година Аингвисти, политичари и културни радници трудили да објасне и теоријски поткују нови приступ језику, тако Аа се понекаА стиче утисак Аа је много више времена потрошено на теоретисање о самој ситуацији од обезбјеђивања ваљаних доказа у пракси. У неколико првих докумената се и не назиру обриси будућег дјеловања, али је касније, нарочито након Симпозијума о језику, било јасно којим путем иду босанскохерцеговачки креатори јавних политика.

\section{1. Аингвистички аргументи}

Теоријских поставки које се могу пронаћи у митератури је много, нарочито ако се узму у обзир сви називи који су предлагани за именовање језика којим се говори у СР БИХ, али се сви они своде на неколико доминантних теоријских упоришта. Наглашавам и то Аа је сваки назив пратило и теоријско и историјско поткрепьење такве тезе.

1. Негирајући подјеку на варијанте, Аалибор Брозовић и Јован Вуковић говоре о коегзистенщији обје варијанте на босанскохерцеговачком nодругjy. Брозовић је тврдио да су у питању „zone i to nedefinirane na kojima se ukrštaju razne osobine varijanata“ (Brozović 1970:7-8. према Baotić 2012: 357). Вуковић је, с Аруге стране, наводио да постоје само Авије варијанте, београдска и загребачка, јер има „повелик број разАика и граматичких (морфолошких и синтаксичких, граматичко правописних и чисто правописних)“( Tanasić 2012: 69), а „Аа нема научних оправдања Аа се у БиХ за употребу језика Аа назив посебне варијанте“ (80).

2. ЏеваА Јахић ће језичку ситуацију у овој земьи називати међуваријантним склопом (Jahić 1990: 15-16. према Baotić 2004: 22). Исто је писао и Стјепан Бабић наводећи да „sada se dakle 
bosanskohercegovački književni idiom, gledan s gledišta standardnosti i normiranosti, može smatrati srpsko-hrvatska međuvarijanta i u popisu slavenskih standardnih jezika ne može dobiti posebno mjesto “ (1985:23),

3. а Срђан Јанковић субваријантом. Јанковић је говорио да језик којим се у овој републици говори није производ укрштања варијаната, већ Аа у Босни и Херцеговини постоји „polariziranost varijantnih jedinica“ (Janković према Baotić 2004: 26). У објашњењима, осу коваријантности назива и осом аваријантности, с обзиром на то Аа овај израз посједуjе „autentično bazično svojstvo eliminisanja varijantne opozicije“ (према Tošović 2012: 538).

4. Светозар Марковић, још један сарајевски мингвиста који учествује у расправи о језику, сматра да се „треба одупријети и оним тенденцијама што воде подвајању језика и оним које иду за тим да се оспори постојање варијаната и њихово право на живот“ (Tošović 2011: 729).

5. Постоје и они који су сматрали да је језик којим се говори у Босни и Херцеговини носикац варијантне неутрализащије и да га карактерише „отвореност према осталим стандарднојезичким изразима српскохрватскога језика у цјелини“ (Šipka 1987: 42).

6. Наима Вањевац говори (и то као једна од ријетких која користи националну одредницу) о анационалном стандарднојезичком изpaзy (Tošović 2009: 352). Слично мисли и Баотић, наглашавајући Aa „raslojavanje na dvije varijante i ostatak koji nije u istoj ravni, nije varijanta, moguće je samo ukoliko se ostatku pripiše svojstvo invarijantnosti, a to znači hijerarhijski ga se stavi u viši položaja (Baotić 2004: 27), односно „Авјема варијантама супротставњен је функционални облик тог језика ослобођен националног набој“ "(Baotić 2005: 448. према Tanasić 2012: 82) и који треба да буде надређен варијантама.

7. Јављали су се они, као Милош Окука, који су сматрами да је у питању један језик (Baotić 2012: 366). Сличан став заступао је и Асим Пецо, који је остао досьедан мишьењу да су остали народи „створили подоста тога, вАаститога и то укьучими у историју и културу наше Аруштвене заједнице“ (Ресо 1984: 119), Аа нови израз није утемељен 
на дијалекатској ситуацији и да „нема никакве потребе Аа се нешто мијења у Авочланом називу нашега језика“ (119).

8. Српски мингвисти редом сматрају да се ради о српском језику и Аа је „Босна и Херцеговина постала једна од четири југословенске републике у којој се употребњавао српски књижевни језик Вуковог типа“" (Tanasić 2012: 65).

9. На крају, најрадикалнији став за то вријеме заступа група стручњака која је сматрала да се ради о трећој варијанти српскохрватског језика (пореА Авије постојеће - српске и хрватске). Исмаим Палић (Tošović 2009: 79) и Алија Исаковић (Tošović 2009: 15), између осталих, сматрали су да су српски, хрватски и босанскохерцеговачки израз три варијанте скужбеног језика. Исаковић је тада, пореА отвореног залагања за засебну варијанту, говорио и о црногорској варијанти равноправној са двије односно три набројане (Baotić 2012: 357).

Иако се може учинити наивним и беспотребним, сви ови Аингвистички аргументи и прилична ангажованост око именовања и образможења идиома који се користи на овом простору били су неопходни творцима језичке помитике, јер су знали да је први корак у њеном стварању именовање језика и оАлучивање о његовој форми, историји, статусу и развоју, Аа би касније дошли Аруги мингвистички задаци, као што су нормирање и стандардизација.

\section{2. Социолингвистички аргументи}

У социолингвистичке аргументе који су пратили језичку политику у Босни и Херцеговини и који су се потезали око термина босанскохерцеговачки језички израз убрајамо све ставове и образцожења који укьучују и друштво - односно који језик посматрају кроз призму босанскохерцеговачких национаАних односа. Сама чињеница да је прва реакција из Босне и Херцеговине дошла управо из Партије, говори у прилог томе Аа ово питање тада, ни прије, а усудићемо се рећи ни послије, није могмо бити само Аингвистичко управо због сложених вјерских а касније националних односа који се у овој републици преливају и на сва остаца питања.

У самој изјави Извршног комитета ЦК БИХ поводом Аекмарације о називу и положају хрватског књижевног језика стоји Аа је Босна и Херцеговина 
svjedočanstvo dosljednog rješenja nacionalnog pitanja u Socijalističkoj Federativnoj Republici Jugoslaviji“ те Aa ce „sva raspravljanja o srpskohrvatskom odnosno hrvatskosrpskom jeziku (...) uvijek moraju posmatrati sa stanovišta njihovog odražavanja na bratstvo i jedinstvo, ravnopravnost i zbližavanje naroda i u SR BIH (Šipka 1999: 134).

ВАасти ове социјалистичке републике нису могме ни подржати ни дозвомити бимо коју језичку политику осим политике заједничког израза за сва три народа јер би то значимо и опасност за тада још стабилно Аруштвено уређење. Касније ће у отвореном писму наставника Филозофског факултета стајати да ова питања „zadiru u bit odnosa naroda ne samo hrvatskosrpskog (srpskohrvatskog) jezičkog prostora nego i cjelokupne jugoslovenske socijalističke zajednice“ (Исто, 137). Аакме, познато је Аа је питање језика отворимо питање народа и народности у национално разноврсној чканици заједничке државе и да је оА рјешавања тог питања зависио опстанак заједнице. ${ }^{6}$

Аингвисти који су били непосредни учесници ових догађаја разАичито тумаче став да Босна и Херцеговина има аутентичан језички стандарА, који је требало Аа прати посебна језичка политика. ЈеАни сматрају да је то био почетак самосталних одмука на пољу језика и да је именовање посебног стандарда умјесто опредјељења за српску или хрватску варијанту или зајеАнички назив спасимо Босну и Херцеговину од сукоба на пову језика, ими констатују да су „водећи мингвисти и Аруштвени чиниоци у БиХ покушали да покажу како је могуће Аа Аисолуција не иде по националним шавовима" (Tanasić 2012: 74). Аруги пак вјерују да је управо овај период био почетак национално-језичког разлаза у Босни и Херцеговини а аа је озваничење босанскохериеговачког језичког израза послужимо неким мингвистима Аа у постратној БиХ нађу оправдање за посебан национални језик.

Тако све судове о оправданости ове политике може сажети став да је израз којим се користе становници Босне и Херцеговине њихова брана оА „напаА[а] на братство и јединство и равноправност у социјалистичкој Југославији, на шта су народи БиХ посебно осјетьиви“" (Tanasić 2012: 76), тако да су

\footnotetext{
${ }^{6}$ То није ништа ново када је у питању Босна и Херцеговина, будући да је језичка политика свих периода била или покушај Аа се надвладају националне подјеме ими настојање да се сузбију националне тежње конфесионалних а касније националних група. Шире в. Александра Савић (2017) „Језичка политика Аустроугарске у Босни и Херцеговини“ у Зборник, Аруштва чланова Матице сриске у Републии Српској, 53-71, Алексанара Савић (2018), „Посьедице аустроугарске језичке политике у Босни и Херцеговини (колебање између националног и наднационалног језика)“, 
Svi istraživački projekti koji su bili u funkciji osvjetljavanja bosanskohercegovačke jezičke situacije, pa i standardnojezičkog izraza, a bilo ih je mnogo, poduzimani s ciljem da se potvrdi jezičko zajedništvo naroda u Bosni i Hercegovini, a potom i izvan nje, a ne da se stvore posebna normativna rješenja koja će bosanskohercegovački standardnojezički izraz diferencirati u odnosu na izraze u drugim sredinama (Baotić 2012: 375).

За разлику од ових ставова, међу неким, нарочито српским, Аингвистима је често мишьење да је политика босанскохериеговачког језичког израза „послужила као база творцима босанског језика да стандардизују њена хрватска обиьежја као бошњачку специфичност, уз додатак нешто оријентализама у мексици (Babić 2015: 80). Нешто бцажи став изнио је Танасић сматрајући да каА се у Босни и Херцеговини почело говорити о посебном изразу, па још каА се почемо инсистирати и на његовању посебности (...) јавњао се страх од Аањег разбијања српског језичког јединства. Већ је постојала опасност Аа српски народ на хрватској страни буде асимимован, а саА ће и у БиХ добити бар посебну варијанту по којој би се српски израз и овАје размиковао од оног у Србији. Проблем је био и у томе што се у Хрватској већ остваривао концепт по коме је варијанта требала да се преобрати у посебан књижевни језик (Tanasić 2012: 84-85).

Хрватски су мингвисти, с треће стране, наглашавами „угроженост хрватског језика и опасност оА његовог утапања у босанскохерцеговачки језички израз“ (Stojkanović 2015: 98) и касније су истицали посебност хрватског језика у БиХ у историјском и теоријском смислу, видно се Аистанцирајући оА босанскохерцеговачког језичког израза.

Опречност ових ставова, што је важно нагласити, није настала у вријеме провођења принципа нове језичке политике. Тада је, наиме, постојала општа сагласност Аингвиста (без обзира на националност) о потреби очувања босанскохерцеговачког језичког и друштвеног јединства. Они који се с тим нису слагали или су скмоњени у запећак језичких истраживања или су сами отишли. Раздор у мишьењу настао је у годинама прије и послије рата, кад је постало јасно да ће се распасти не само језик него и цијела Аржава. Аругим ријечима, оно што је некада служило као социолингвистичко оправдање за постојање новог израза сада је послужимо као социолингвистички изговор за разцаз. 


\section{4. Умјесто закьучка - стандардизација језика ими припрема за национамне језике?}

На претходним страницама описана је језичка политика СР Босне и Херцеговине оА 1970. до 1991, то јест истакнуте су најважније особине те по-

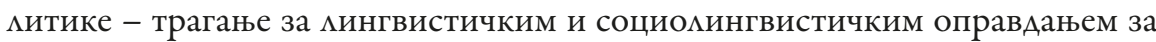
стандардизацију новог израза. Та политика имаха је неколике мањкавости оА којих можемо истаћи двије кључне - прво, започета је политичком изјавом, не тако непромишьеном, ами ипак исхитреном, јер ће тек касније услије-

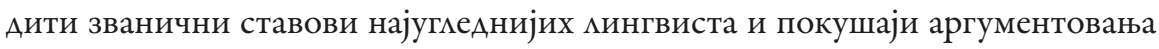
политичке воље, који ће завршити утркивањем јеАног дијела стручњака Аа аргументовано објасне унапријед осмишьене задатке језичке политике, и друго - умјесто да закьучцима и измјенама језичке политике претходе исцрпна истраживања и рад на терену, било је обрнуто, па се тек након утемељења новог политичко-језичког курса оснива Институт и ради се на томе Аа се већ донесене оцјене потврде у пракси. Када су сви набројани кораци бими испуњени, једини који је преостао био је нормирање тог израза. Међутим, до тога није дошло а разцози које понегдје успијемо наћи у митератури говоре о разним препрекама - од теорија завјере Ао чињенице да је рат спријечио Ааљи рад на језичкој политици, иако други не сматрамо релевантним, будући да је почетни ентузијазам нестао и много прије рата. С обзиром на то да је првобитни замах политике и планирања језика врло брзо спласнуо, можемо поставити сасвим оправдано питање - који је био циь успоставьања ове политике? Стандардизација посебног језичког израза или прелазна фаза ка националним језицима?

Ако описану ситуацију посматрамо кроз Радовановићеве фазе у стандардизацији сваког језика7 , увиђамо одређене специфичности. Наиме, двадесет година бимо је довољно за тек прве Авије фазе нормирања језика (селекција и дескрипција), иако ни оне нису спроведене до краја због неслагања око назива, статуса и теоријског упоришта новог израза. Што се осталих фаза тиче, оне су у правом смислу ријечи спроведене тек након рата у Босни и Херцеговини, током успостављања национацних језика.

Фазе кодификације, елаборације, култивације, експанзије и евакуације босанскохериеговачког книжевнојезичког стандарда наступиме су тек након што је он

${ }^{7}$ 1. Фаза селекције (одабирање), 2. Фаза дескрипције (описивање), 3. Фаза кодификације (прописивање), 4. Фаза елаборације (разрађивање), 5. Фаза акцептуације (прихватање), 6. Фаза имплементације (примјењивање), 7. Фаза експанзије (ширење), 8. Фаза култивације (његовање), 9. Фаза евакуације (вредновање) и 10. Фаза реконструкције (преправљање). 
узет као основица језика Бошњака ${ }^{8}$, с обзиром на то да „,za korisnike standardnog bosanskog jezika, osim izmjene njegova imena, gotovo da i nije, u tom raskolu, trebalo vršiti druge značajnije korekcije u postojećoj normi bosanskohercegovačkog standardnojezičkog izraza na koji se bosanski jezik direktno naslanja" (Valjevac 2003: 29).

Такође, босанскохериеговачки стандарднојезички израз није прошао ни фазу прихватања и одобравања оА стране грађана, што видимо из пописа становништва из 1991. године. Наиме, ако објединимо све резултате који би могли да се односе на овај период језичке стандардизације, јер назива босанскохерщеговачки къижкевнојезички израз у попису није било, увиђамо да се тек нешто мање од пет оАсто становника изјаснимо да им је матерњи језик нека варијанта босанскохерцеговачког језика (југословенски, босанскохерцеговачки, босанскосрпскохрватски, бошњачкосрпскохрватски, херцеговачкобосански, босанскојугословенски $)^{9}$.

Уколико узмемо у обзир чињеницу да су у двадесетогодишњој језичкој помитици спроведене тек фаза описивања новог језичког израза и фаза семекције језичког варијетета, а Аа је осам осталих изостало, можемо оправдано тврдити, прво - Аа се језичка политика од 1971. до 1991. не може посматрати одвојено оА периода који је услиједио нити доживљавати као посебан период у развоју језика јер постоји очигледна подударност између ове језичке политике и језичке политике Бошњака након рата, а у којој су наведени елементи стандардизације спроведени у Ајело у националном језику, и друго - да је језичка политика босанскохериеговачког језичког израза поскужима као припремна фаза за будуће издвајање националних језика и да је треба тако и анализирати.

\section{Митература}

1. Baotić, Josip (2004), „Književnojezička politika 1970-1990, Borba za zajedništvo i ravnopravnost", Književni jezik, 22/1-2, Sarajevo: Institut za jezik.

2. Baotić, Josip (2012), Približavanje jeziku ili približavanjejezika, Sarajevo: Slavistički komitet.

3. Peco, Asim (1984) „Naš jezik i njegovo ime“, Književni jezik, 13/3, Sarajevo: Institut za jezik.

\footnotetext{
${ }^{8}$ Овдје мислимо прије свега на нормативне рјечнике, правописе и граматике „босанског језика“ објављене деведесетих, као и на ширење тог стандарда и изван граница БиХ.

9 Попис становништва, домаћинстава, станова и повопривредних газдинстава 1991. http:// fzs.ba/index.php/popis-stanovnistva/popis-stanovnistva-1991-i-stariji/.
} 


\section{АЛЕКСАНДРА Р. САВИЋ}

4. Škiljan, Dubravko (1988), „Prolegomena našoj jezičnoj politici“, u: Pupovac, Milorad (1988), Jezici i politike, Zagreb: Komunist.

5. Valjevac, Naila, (2003), „Bosanskohercegovački dijalekatski kompleks i bosanska standardnojezička norma“, Književni jezik, 21/2.

6. Бабић, Миманка (2015), „Босански проблеми српског језика у БиХ“, Узданища, $\mathrm{XII} / 1,77-85$.

7. Попис становништва, домаћинстава, станова и пољопривредних газдинстава 1991, http://fzs.ba/index.php/popis-stanovnistva/popis-stanovnistva-1991-i-stariji/.

8. Радовановић, МилораА (2003), Социолингвистика, Нови СаА - Сремски Кармовци: Издавачка књижарница Зорана Стојановића.

9. Савић, Александра (2017), „Језичка политика Аустроугарске у Босни и Херцеговини“, у: Зборник Аруштва чланова Матице српске у Републиии Српској, Бања Аука: Аруштво чианова Матице српске у Републици Српској.

10. Савић, Александра (2018), „Посьедице аустроугарске језичке политике у Босни и Херцеговини (комебање између националног и наднационалног језика)“, научни скуп Крај првог свјетског рата и настанак југословенске државе, АНУРС, у штампи.

11. Стојкановић, Александар (2015), Сочиолингвистичка анализа језичке политике у постдејтонској Босни и Херцеговини, необјавьена докторска дисертација.

12. Танасић, Срето (2012), „Језичка политика у Босни и Херцеговини послије Аругог свјетског рата“, Значај српског језика и книжевности у очувағу идентитета Републике Српске I, Фимозофски факултет Пале, 65-102.

13. Тошовић, Бранко (2005-2012), Српски погледи на односе између српског, хрватског и бошььаког језика I/5, БеограА-Грац: Београдска књига - Универзитет Грац.

14. Тошовић, Бранко (2009), Бошғачки погледина односе између босанског, хрватског и српског језика, БеограА-Грац: Београдска књига - Универзитет Грац.

15. Тошовић, Бранко (2010), Хрватски погледи на односе између хрватскога, српскога и босанскога/бошњачкога језика, БеограА-Грац: Београдска књига - Универзитет Грац.

16. Тошовић, Бранко (2011), Српски погледи на односе између српског, хрватског и бошъачког језика I/3, БеограА-Грац: Београдска књига - Универзитет Грац.

17. Тошовић, Бранко (2012), Српски погледи на односе између српског, хрватског и бошњачког језика I/4, БеограА-Грац: Београдска књига - Универзитет Грац.

18. Шипка, Миман (1975), Језички савјетник, Сарајево: Свјетлост.

19. Шипка, Милан (1987), Кюижевнојезичка политика и језичка култура, Сарајево: Ослобођење.

20. Шипка, Микан (1999), Стандардни језик у Босни и Херцеговини у документима језичке политике, Сарајево: Отворено аруштво. 
Aleksandra R. Savić

\title{
INTERPRETATIONS OF THE TERM BOSNIAN- HERZEGOVINIAN LANGUAGE EXPRESSION AND THE LANGUAGE POLICY THAT ACCOMPANIED IT
}

\begin{abstract}
Summary
In this paper we analyse the term Bosnian-Herzegovinian language expression, which was developed by politicians and linguists in this country from 1967. to 1990. After the Serbian-Croatian language split, language politics creators in Bosnia and Hercegovina debated about possibilities to support a specific language type and to promote tolerance and indvidual choice in a national divided society. We disscused this concept and the reasons why this expression was chosen. The main goals of linguists were to describe and legitimate a new path in language politics. They used language (linguistic) and political (sociolinguistic) arguments to present the Bosnian-Herzegovinian language expression. This phase had the same consequences like any other period in this country when politicians and linguists tried to create a common language - national groups rejected it and decided to have their own national expressions. Also, using Radovanovic's ten phases of standardisation, we concluded that only two phases of language standardisation were adopted (selection and decription). Others (prescription, elaboration, acceptance, implementation, expansion, evaluation, reconstruction) finished in post-war national language politics.
\end{abstract}

